\title{
Legal Reality as a Jural Category
}

Skorobogatov A.V.

Institute of Economics, Management and Law, Kazan, 420111, Russia

Email: lenar_s@mail.ru

Bulnina I.S.

Kazan Federal University, Institute of Management, Economics and Finance, Kazan, 420008, Russia

Krasnov A.V.

Kazan Federal University, Institute of Management, Economics and Finance, Kazan, 420008, Russia

Email: lenar_s@mail.ru

Tyabina D. V.

Kazan Federal University, Institute of Language, 420008, Kazan, Russia

\section{Doi:10.5901/mjss.2015.v6n3p664}

\section{Abstract}

The article studies legal significance of the category «legal reality». There is the author's definition of the category. The basic elements of the given category are considered. The conclusion is made that legal reality as a fundamental jural category is a complex multilevel system that includes the entirety of real legal phenomena and legal ideal. The system determines the sphere of legal being both individual and social.

Keywords: legal reality, category of jurisprudence, legal science, legal being, legal phenomenon, post-modernist law interpretation concepts, postclassical expediency, methodological pluralism, legal behaviour, anthropological and legal research.

\section{Relevance of the Issue}

General legal theory has an important and actual destination - detection and study of the fundamental notions and categories that characterize the essence and content of social legal being [18]. One of such categories, which has been introduced in scientific rotation and has not been studied so far both in general legal theory and legal philosophy, is «legal reality».

\section{Bibliography Review}

The term «legal reality» has been mentioned in the works of foreign existential and phenomenological oriented legal philosophers since the mid XX century. (G. Cohn [5], A. Kaufman [11; 12], M. Salter [16], W. Hamrick [9], E. Fechner [7], M. Moore [15]). This notion is mainly used to define the reality of certain legal phenomena [3; 8]. The research does not examine the concept of the given notion.

Since the mid 1990-ties this issue has gained relevance in the post-Soviet space. Many philosophers (V. A. Bachinin [25], G. I. Ikonnikova, V.P. Lyashenko [28], S.I. Maksimov [30; 31], I.P. Malinova [32], S.L. Slobodnyuk [35]) and law theorists (A.V. Polyakov [34], I.L. Chestnov [39], Yu. S. Shemshechenko [40]) turned their attention to it virtually at the same time. The use of the term is mainly taken in the sense of intergrative law interpretation. It is urged to overcome one-sidededness of positivism, sociological and natural legal theories by means of creating an integral category, which would join and structure various legal phenomena.

The aims of the article are to receive certain scientific knowledge on legal category «legal reality», to detect and analyse ontological and gnosiological sense of the notions. It determines the core functions of the legal phenomena in a particular society. [20]. 


\section{Methodology}

The sufficient and diverse study of the assigned issue encouraged its research by the means of a considerable amount of methodological tools elaborated not only in the framework of legal science but also in the framework of other humanitarian sciences.

The fundamental methodological approach taken in the project is a dialectical one, which examines general regularities of forming the essence and content of the legal reality.

The system-functional feature of legal reality takes its separate place among the used methods. It stipulates to observe the functional characteristic of legal reality.

The historical method enables to examine the genesis of legal reality formation in retrospective. It has the goal to detect the aspects that are important to modern legal ontology and stipulates the trends of further legal improvement. In addition the article has formal and logic method in combination with its tools such as analysis and synthesis, induction and deduction, analogy and generalization. These means enable to expand the essence and content of the legal reality phenomenon.

\section{Summary of the Article}

The given methodological approaches and methodology make it possible to consider legal reality as one of the fundamental philosophical and legal category of modern humanitarian sciences. They enable to analyze it in institutional, functional and subject and object context.

At present there appeared a great amount of categories, which are close to the researched one: legal system, legal life, legal culture, legal conscience, legal actuality, legal practice and others. Justification of the independence of legal reality category implies outlining its substantial features that don't match the essential features of the enumerated categories.

The Ukrainian legal philosopher S.I. Maksimov gave his definition of the category. Among the variety of philosophical and jural definitions of legal reality his definition is considered to be the most congenial to the content of the category and pretends to reflect its essence: it is regarded as a multilevel system of legal phenomena, separate metasocial reality and its meaning content is mutual obligation in interaction of subjects [31, p.45]. It should be stressed that in this sense it is important to underline the mutual obligation of subjects' interaction, which draws closer the essential view of legal reality and communicative law concept having been developed in Western science originally [22], but at present it is also being enhanced in the domestic jurisprudence [33]. In its turn, the works of foreign scholars stress the peculiar role of speech, rhetoric, interpenetration of language and culture. In particular, the article studies the jural narration in detective stories, which give better understanding of the jural reality [19, p.93-94].

Following S.I. Maksimov we realize legal reality as the category that defines special partially independent law world, multilevel system of legal phenomena, determining the process of social interaction.

On the basis of the above legal reality might be defined as peculiar legal being in particular space-time continuum. Joining the entirety of legal phenomena in social sphere this category assumes dialectically that legal phenomena of objective and subjective realities can exist both in close interaction and separately from each other [26, p. 40]. On the one hand jural array defines legal behaviour of an individual and society, on the other hand social legislative efficiency is stipulated by both its demand in the society and a particular individual's actions toward the realization of certain legal standards. Although legal reality is not the basic part of reality, but it is only a way of organization and interpretation of certain aspects of individual's and society's legal being, it does not have strict material borders. It exists in both material level and mental one simultaneously.

Legal reality includes three aspects: objective (the existence of legal regardless an individual and society), subjective (individual's actions in legal sphere are connected with his legal consciousness), irrational (to a considerable degree individual's legal behaviour can be explained by accidental motivation)[24, p.15-16]. Here we cannot but agree with S.L.Slobodnyuk's opinion about extremely objective feature of legal reality («legal reality is objective and definitely proposes the existence of an individual that enters into legal relations» [35, p.32]). It is thought that this category has more complex subject and object character. In each segment of legal reality - whether it is law, law realization or something else- it is impossible to detect phenomena that are independent entirely from the impact of subjective factors and subject interpretation. [6]. Furthermore, the assigned issue is hampered by the question of objectivity and law materiality: whether it is possible to talk about extremely such features of law or it still has certain subjective and ideal features. Unlike traditional theories of law understanding that pursue the revelation of key legal notions and their places in legal system $[13$, p.3, 6-8], many of postmodern concepts, which gained popularity in XX century, consider law as a 
complex phenomenon. Integrativism, in particular, stems from impossibility to explain law through only single scientific theory. Moreover, the very postclassical scientific rationality bases on the idea that subject cannot be separated from object, object has a subjectivized character and subject has objectified one [23, p.727]. A law scholar exists in the researched legal reality and his conclusions cannot pretend to have absolute objectivity. [17, p.1733].

The essence of legal reality implies organization of the people's behaviour in human society In an attempt to archive stable social organization on the regular basis.

With regard to such approach to the essence of legal reality, it corresponds a compound organized social system, which might be considered in dialectical interconnection of multilevel structural components, which will be described in detail below.

Among the features of the given category it is suggested to focus on regulatory distinctness, formality and imperative one [29, p.13]. Actually, unlike other normative systems (religious, moral, corporative), law has peculiar power - regulating nature based on the possibility of state compulsion prima facie. Institutional provision of proper law standard functionality by means of jurisdictional lever application is carried owing to proper juridical norm setting in corresponding formal law sources. Originally imperative feature of law implies inseparable connection between law as essential element of social reality and power-regulating subject (state, society, local community and others). However in our opinion it is hardly reasonable to shift the properties of the part (the rule of law, legislature) to the whole item as wider and more compound system (legal reality). The given properties are usual to the rules of law; it cannot be attributed to subjective elements of legal reality, namely, legal behavior, which is founded on certain mental views and notions. The latter may not conform to the formal legal norms and statements.

Referred above O.V.Kret emphasizes ontologically three fundamental components in the structure of legal reality lawmaking (activity toward creation, improvement, changing and abolition of legal norms), law realization (process, system means and measure toward actual law system enforcement, and achievement of the assigned objectives) $и$ law enforcement (activity, oriented to prevent the existence of law violation, and the use of state compulsive measures in case it happens). The components play their functional roles in the interconnection with each other and the whole structure. As stated above, malfunctions of the given components (gaps in the law, legal conflicts, absence or отсутствие или inefficiency of legal regulation mechanism, etc.), exceeding the threshold value, may bring both the development of the current legal reality and its elimination [29, p.8]. In our viewpoint law enforcement must be regarded as one of the direction of lawmaking and law realization accordingly: protection of the rights is guided both through consolidation of certain regulations in law standard and their enforcement. Thus the emphasis of the law enforcement in the same row with lawmaking and law realization is contradictive logically to the laid conceptual and categorical notions in legal science.

Both dialectical and system and structural methods are used during the research of legal reality. There is no doubt that philosophical and dialectical method remains to be one of the most authoritative and elaborated one, which enables research legal reality from the standpoint of cause-and-effect relation, with regard of principle of determinism in connection with related phenomena, in addition to dynamic and regarding the historical retrospective. However there is an idea that at present it is not wise to refuse of other methodology, which help to comprehend these or those legal phenomena, in the current period of scientific development in general and legal science in particular. Namely, it is not worth refusing from synergy, phenomenology and other methodological approaches we should agree with the becoming more and more popular idea of methodological pluralism in domestic humanities. [27, p.125-130; 37, p.32]. it is thought that the mentioned pluralism leads to not only simple sum of means and approaches, and ways of result description, but to the belief that any object of research, especially those that are in social and humanitarian sciences, may be interpreted differently; in addition different manifestations can be studied. The claims of this or that methodology to be absolutely truthful seem at least naïve [2].

There are three elements in the framework of the system methodology in the structure of legal: law (the system of social relations regulation stipulated by human nature and social nature система. The system had inherent features such as normativity, formal distinctness in official sources and provision of possible state compulsion); legal relationship (standard adjusted rights, public relations, when participants have subjective rights and jural duties, protected and provided by the state); sense of justice (the set of views and ideas expressing people's, social groups' and classes' attitude to law, legality, justice, their ideas of what is right and what is wrong.

The use of phenomenological methodology, in its turn, enables to study legal reality as multilevel phenomenon. On the basis of the most significant spheres of legal activity 2 main levels: lawmaking (the set of legislator's actions in an attempt to form law order, legal regime and the set of regulations) and law realization (the set of individual's and authorized persons' actions on regulations enforcement, created in the result of these actions). Law in its regulatory, legislative form acted as an integrated platform of legal reality and connecting component of all its level and elements. Ideally justification of law implied not only interconnection of the written law and justice (unwritten law) but also their 
mutually complementary roles in social regulations. In crisis, however, in the absence of sufficient effective jural and social mechanism of law enforcement there is the third level of legal reality - legal behaviour, i.e. behaviour which conforms to social views of justice. At the same time it does not present any importance to the individual how these "right actions" conform or contradict to "bad" legislasture. Law is becoming to be the integrated base of legal reality, which due to the separation between law and justice is gaining transgressive, mosaic feature. To a considerable degree the formation of the legal relationship occurs on the base of "wrong" rules and practice, the content of which is defined by an individual (it forms on the basis of synthesis of legal consciousness and interaction of individuals in legal sphere expressed in knowledge, skills and habits) and supra-individual legal experience (it forms on the basis of synthesis of legal ideal, legal mentality and under the influence of legal socialization agents expressed on certain legal situations and their formal enhancement) [38].

It is obvious that each of the legal reality level has mixed, object and subject character, as it was mentioned above. Both lawmaking activity and law enforcement are the processes closely connected with mental understanding of law, justice, obligation and non-obligation.

The measure of legal reality order is the jural notion of law order, taken as law-based organization of social life. It reflects qualitative condition on a certain stage of social development. Legal regulation has the possibility to influence on legal relationship and legal consciousness (legal understading) as long as actual justice (enshrined in a regulatory act) remains equal to notion of justice (a pattern of social justice). As soon as the equality loses its significance, legal understanding acquires horizontal and vertical conflicts, and legal consciousness becomes to contradict legal regulations, forms absolutely new legal relationship. Moreover in some cases it can have the ability to change legal reality qualitatively

The problem of maintaining of legal reality is connected with a question on criterion to attribute these or those phenomena to legal ones. It should be mentioned that the designated problem cannon be resolved definitely: the concepts of legal understanding have principally different criteria on what is «legal» [10]. For instance, jural positivism traditionally connects law with state and its compulsive power. At the same time despite the attempts of natural-law school to connect rule of law with basic moral values there are other criteria, namely, effectiveness and efficiency of the law. [4]. The representatives of American Pragmatic School, in its turn, propose new pragmatic methodology, which enables to solve conflicts between natural law concept and jural positivism. There are three main principles that should be laid: causality principle (respect to a person as a rational being with goodwill), principle of consent (regulation bases on the consent of the governing and the governed), isolation principle (i.e. autonomy, independence of law from authority of the given political power) [21].

As it seems the perspective of research of the legal reality content may be designated in connection of anthropological and legal investigation. A man creates law himself, applies it, being involved in legal reality directly. Notwithstanding the substantial objective part of the legal phenomena, legal reality cannot be considered outside the inner and psychological relations of the subject (subjects) to legal phenomena. Being a social creature a man enters into many relations simultaneously.

In its turn, there appears a question of legal restrictions to other social phenomena: where is the limit of legal and social reality? It is well-known that law cannot be regarded metaphysically, out of context of other social norms and social phenomena which somehow influence on it or (and) interact with law and its elements [1]. Meanwhile it is still difficult to draw a boundary between «legal» and «illegal» [14]. Even professor Syryh V. M., acting as an apologist of materialistic concept of law, denotes not only state, law but also legal and state practice and other form of social practice, closely connected with state and law as the object of research in legal science. [36, p.38]. The research of «somehow legal» phenomena, which can be counted as legal in some circumstances, the given research direction can give fruitful results while description and analysis of the legal reality.

\section{Conclusions}

Thus legal reality can be considered as the fundamental jural category that identifies the special form of social reality. Legal reality is a complex multilevel system that includes the entirety of real legal phenomena and legal ideal and it determines the sphere of legal being both individual and social.

\section{References}

Alexy R. On Necessary Relation between Law and Morality // Ratio Juris. 1989. N 2. P. 167 - 183.

B. Patrolling the Boundaries: Inclusive Legal Positivism and the Nature of Jurisprudential Debate // Canadian Journal of Law and Jurisprudence. 1999. N 12. P. 17 - 33. 
Gordon R.W. Unfreezing Legal Reality: Critical Approaches to Law //Florida State University Law Review. - 1987. - Vol. 15. - \# 2. - P. $137-151$.

Hamrick W.S. An Existential Phenomenology of Law: Maurice Merleau-Ponty. - Dordrecht: Martinus Nijhoff Publishers, 1987. - 246 p. Hoerster N. Die rechtsphilosophische Lehre vom Rechtsbegriff // Juristische Schulung. 1987. Vol. 27. S. 181 - 188.

Kaufman A. Preliminary Remarks on a Legal Logic and Ontology of Relations // Law, Interpretation and Reality. - Dordrecht, 1990. - P. 104-123.

Ibragimov M., Tufetulov A.M. Income distribution and market demand: the case of heterogeneous preferences // Mediterranean Journal of Social Sciences vol. 5 № 24, November 2014, pp. 185-187.

Kennedy D. Toward an Historical Understanding of Legal Consciousness: The Case of Classical Legal Thought in America 1850-1940 // Researches in Law and Sociology. 1980. N 3. P. 3-24.

Sherwin R.K. The Narrative Construction of Legal Reality // Journal of the Association of Legal Writing Directors. $-2009 .-$ Vol. 6. - P. 88-120.

Twining W. Huge Concepts, Will Travel: Analytical Jurisprudence in a Global Context // International Journal Law in Context. 2005. N 1. P. $5-40$.

Tyler J. A Pragmatic Standard of Legal Validity. Dissertation. - Texas A7M University (2012) URL: http://philpapers.org/rec/TYLAPS.

Van Hoecke M. Law as Communication. - Oxford - Portland Oregon, 2002. - 234 p.

Winter S. L. The «Power» Thing // Virginia Law Review. 1996. Vol. 82. N 5. P. 721-835.

Safiullin, M.R., Safiullin, A.R., Elshin, L.A.,Prygunova, M.I. Matrix approach to assessing competitiveness of regions: From methodology to practice. Asian Social Science, 10, pp. 47-56

Demidov A.I. Pravovedenie: ot metodologicheskogo anarhizma k metodologicheskomu plyuralizmu // Gosudarstvo i pravo na rubezhe vekov: Problemyi teorii i istorii (materialyi Vserossiyskoy konferentsii). - M.: Izd-vo IGiP RAN, 2001. - S. 125-130.

Ikonnikova G.I., Lyashenko V.P. Osnovyi filosofii prava. - M.: INFRA-M, Ves mir, 2001. - 256 s.

Adigamova Farida F., Safiullin Marat A., Tufetulov Aidar M. Mechanism of state tax regulation in the global economy // Mediterranean Journal of Social Sciences vol. 5 № 24, November 2014, pp. 193-199

Maksimov S.I. Pravovaya realnost: opyit filosofskogo osmyisleniya. - Harkov: Pravo, 2002. - 328 s.

Polyakov A.V. Obschaya teoriya prava: fenomenologo-kommunikativnyiy podhod. - SPb: Yuridicheskiy tsentr press, 2003. - 845 s.

Slobodnyuk S.L. Pravovaya realnost i krizis pravosoznaniya. - Saarbr

Safiullin M.R., Safiullin A.R. Structural analysis of the dynamics of petrochemical cluster of Republic Tatarstan. Mediterranean Journal of Social Sciences vol. 5 № 24, November 2014, pp. 300-306 . 